\title{
Role of Leptin in Cancer: A Systematic Review
}

\author{
Noreen Samad* and Tazeen Rao \\ Department of Biochemistry, Pakistan \\ *Corresponding author: Noreen Samad, Department of Biochemistry, Pakistan
}

\begin{abstract}
ARTICLE INFO
Received: 酗 May 07, 2019

Published: 慧 May 14, 2019

Citation: Noreen Samad, Tazeen Rao. Leptin, Adipocytes, Cancer, Angiogenesis, Apoptosis, Autoimmune Response. Biomed J Sci \& Tech Res 18(1)-2019. BJSTR. MS.ID.003091.
\end{abstract}

Keywords: Leptin, Adipocytes, Cancer, Angiogenesis, Apoptosis, Autoimmune Response

\begin{abstract}
Adipose tissue is recognized as an active endocrine organ secreting bioactive adipokines (leptin and adiponectin) which regulate physiological and pathological processes, such as appetite, insulin sensitivity and resistance, inflammation, immunity, hematopoiesis, and angiogenesis. Leptin is widely considered as adipocyte-inferred hormone that through various receptors inside hypothalamus can control nourishing conducts. It has stimulatory role in cancers like breast cancer, lungs cancer, colorectal cancer, uterine cancer, thyroid cancer, and pancreatic cancer by increasing proliferation, migration potential, angiogenesis and invasion as well as decreasing apoptosis. Leptin, on the other hand, has inhibitory role in cancers by activation of NK (natural killer) cells and autoimmune response. The aim of this systematic review is to evaluate and report the potential importance of leptin in cancer pathogenesis (directly) and via various associated diseases (indirectly).
\end{abstract}

\section{Introduction}

Leptin has been referred to one of the satiety hormones. Leptin is a peptide hormone contains 167 amino acids, $16 \mathrm{kDa}$ protein encoded by LEP qualities that delivered by adipocytes and has part in keeping up vitality adjust. It is a protein hormone that expressions in the hypothalamus decline the adiposity. It is different in their activity that is the reason additionally called as pleiotropic hormone [1]. It assumes imperative part in both natural resistance and versatile invulnerability. Leptin-lacking individuals have weakened insusceptibility. It influences cytotoxicity of NKs; now and again it has cytotoxicity-decreasing impact and in some cases, it improves the cytotoxicity [2]. Several studies on cancer incidence link the predisposition to develop certain types of cancers (e.g. colon, thyroid, esophagus, pancreatic, endometrial, and postmenopausal breast cancer) with an individual's excess body mass/obesity [2]. Leptin is widely studied factor both in general metabolism and in obesity related cancers [3]. Leptin may balance diverse components in a few frameworks, for example, actuating or hindering the progressing steps of the disorders, and the learning of the relationship amongst obesity and cancer makes leptin an examination focus for different sorts of cancers [4].

Leptin, a cytokine that is hoisted in obese people, and cancer progression [5]. While the effect of overabundance body weight, the connection amongst obesity and carcinogenesis is simply being perceived. The component of fat tissue-actuated growth is not known, but rather a few conceivable situations can be imagined. On account of hormone-dependent neoplasms such as breast cancer; increased production of growth factor and secretion of estrogenic compounds, insulin/IGF pathways, angiogenic stimulators by excess fat tissue could subsidize to tumor growth and metastasis [6]. Our aim is to identify and review those studies that have been investigated the role of leptin in different malignancies/ cancers. Currently a lot of work is being done on leptin because it is involved in multiple complex disorders; a thorough understanding of its pathways can provide opportunities to diagnose and treat disorders. Several signaling pathways then can act as therapeutic targets to cure diseases i.e. cancer. The following questions were addressed in this study:

a) What's the reason leptin is considered so important?

b) What's the role of leptin in cancer? (Stimulatory/ Inhibitory)

c) How leptin is involved in regulation of apoptosis through natural killer cells?

d) What can be done to treat cancer by manipulating leptin signaling pathways? 
Our 2nd aim was to use our evaluation for making suggestions for future research to synthesize some chemicals that can act through inhibiting the leptin signaling pathways to cure cancer. In case of cancer leptin level is high so we have to develop strategies to bring this down to normal level; which hopefully will help to prevent cancer by influence action of leptin on cell growth.

\section{Material and Method}

\section{Literature Search Strategy}

Original research concentrates the analyzing the relationship amongst leptin and malignancy through literature seek in three electronic databases Google scholar, PubMed and Research gate (since 2000). The writing pursuit was performed during April (2018) by six inquirers. Exploration incorporate a blend of keywords significant to our concerned theme "leptin and cancer." These electronic pursuits were extended by a manual find of reference segments in article distinguished by electronic inquiry and other applicable sources.

\section{Study Selection}

All broad, peer-explored literature is incorporated and was viewed as reasonable for consideration. The examination confirms identifying with relationship of leptin with autoimmunity issue, cardiovascular maladies is a far from the point of our study.

\section{Data Extraction}

Material withdrawal was conducted utilizing systematize format made for the review and each article was assessed by two analysts. The information uprooting was affirmed for its intactness and validity by analyst. The accompanying information was separated: Leptin, impacts of leptin, hormonal secretion and immunity, finding on association of leptin with various cancer, role of angiogenesis and treatment of cancer.

\section{Data Synthesis}

Information was sorted out as indicated by type of cancer that is regulated by leptin. Where investigation set forth outcomes about different sorts of cancer related with leptin, information was incorporated in all related portions. In the event that exclusive a predetermined number of studies (<3contemplates) exhibited information for particular kind of disorders (cancers) information were not narratively incorporated as no conclusion can be drawn. These incorporate information about Leptin effect on immunity, regulation of cancer by leptin, angiogenesis and leptin, stimulation of breast, ovary and colorectal cancer, inhibition of Pancreatic cancer and treatment of cancer through leptin.

\section{Leptin and Mechanism of Gene Expression}

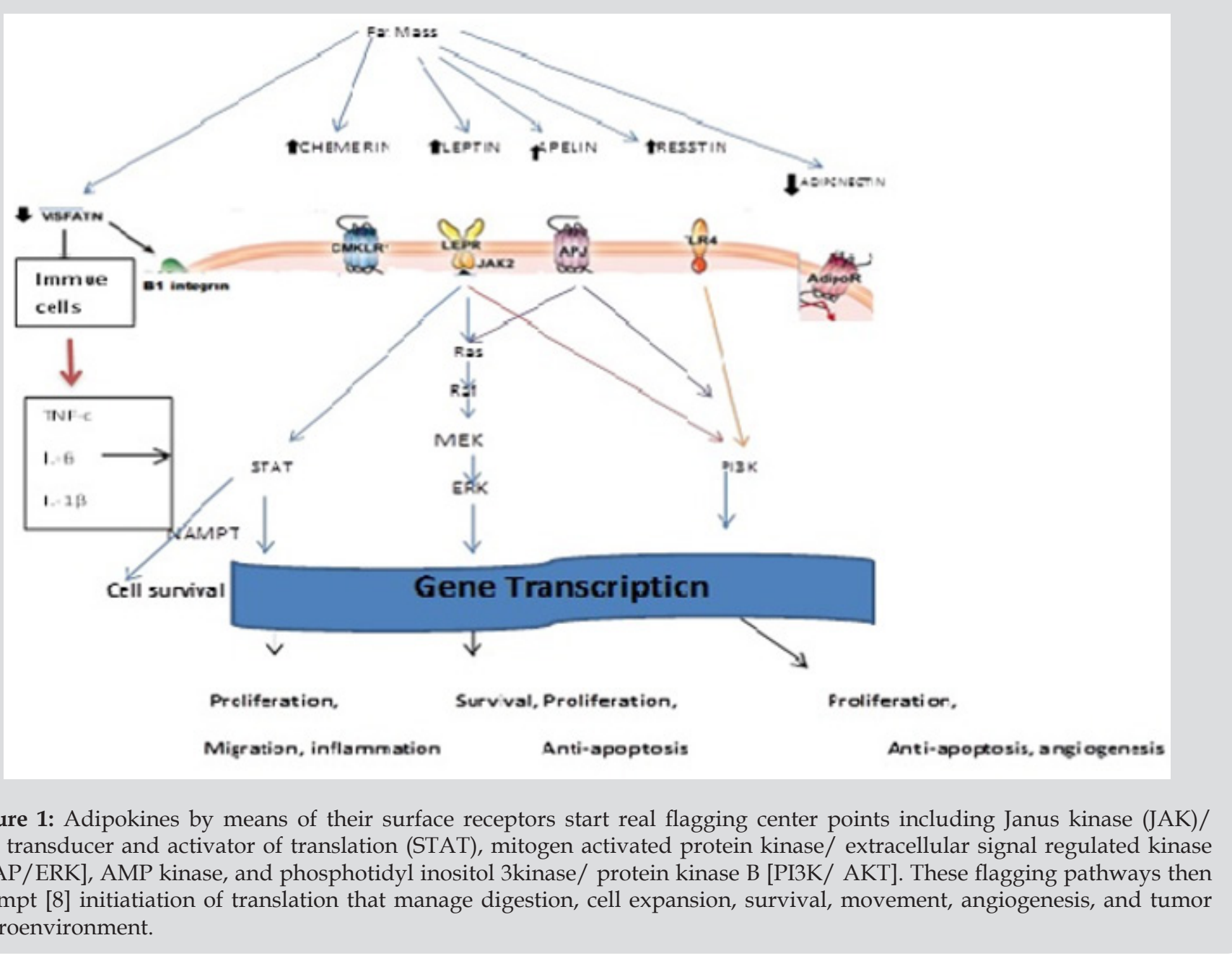


Leptin is released by fat tissue and directs vitality homeostasis, glucose and lipid digestion, resistant capacity, and different frameworks. Leptin via its particular receptor actuates different intracellular flagging pathway [7]. It actuates standard transduction pathways that assume a key part in cell development. Adipokines can actuate real flagging systems like JAK/STAT, mitogen activated protein kinase/extracellular signal regulated kinase [MAP/ERK], adenosine monophosphate [AMP] kinase and phosphatidylinositol 3 kinase/protein kinase B [PI3K/AKT]. All these flagging pathways are included in quality interpretation that directs cell survival, cell expansion, relocation, intrusiveness, angiogenesis and tumor microenvironment [8]. Notably, nicotinamide phosphoribosyl transferase [NAMPT] is alike to visfatin, yet here we elude to intracellular visfatin as Nampt to mean its nicotinamide phosphoribosyl-transferase enzymatic action. NAMPT also known as pre-B-cell colony-enhancing factor 1 (PBEF1) or visfatin is an enzyme that in humans is encoded by the PBEF1 gene. This protein is the rate-limiting enzyme in the salvage pathway [9]. NAMPT has also been reported to be a cytokine PBEF that promotes B cell maturation and inhibits neutrophil apoptosis [10]. Diagrammatic illustration of intracellular signaling pathway by leptin is as shown in Figure 1.

\section{Role of Leptin in Cancer}

Disease propagation is a multistep procedure including different strides, for example, start of tumor, essential tumor development, intrusion, and metastatic movement which includes complex connection with different stromal parts including endothelial cells, insusceptible cells, fibroblasts, and adipocytes [11]. Leptin bind to its receptor $\mathrm{Ob}-\mathrm{R}$, a product of the $\mathrm{Ob}$ gene, to apply its impact [12]. Leptin and its receptors both are missing in ordinary epithelial breast tissue however over-expressed in cancer particularly in breast malignant cell and, represent a poor prognostic factor, related to the presence of remote metastasis and short survival [12-14]. Through an autocrine mechanism leptin is mainly concerned in incitement of estrogen dependent breast cancer $[15,16]$. Leptin diminishes the viability of breast cancers remedies by inciting cell development, transformation and survival $[5,12,17]$. Stimulus for the increase and survival of cancer cells is sirtuin dependent NAD dependent deacetylase 1[SIRT1], a downstream target of leptin $[18,19]$. SIRT1 is over-expressed in cancer such as prostate, breast and gastric cancer and in lymphoma and sarcomas [20-22]. Leptin intervenes epithelial-mesenchymal transition in numerous tumors, for example, lung, breast, and colon cancer $[23,24]$. Down-regulation of the apoptotic reaction [25, 26] and upregulation of cell cycle is due to the pro-carcinogenic impact of leptin [27, 28]. PI3K/AKT pathway has a vital part in oncogenesis in different tumors like colorectal cancer, hepatocellular cancer and endometrial cancer [29]. AKT has a vital part in growth cell survival by advancing glycolysis and keeping up mitochondrial film potential [30]. Leptin and its receptor in carcinogenesis has been expounded. $\mathrm{X}$ linked inhibiter of apoptosis protein [XIAP] in an individual from anti-apoptotic proteins and is a physiological substrate of AKT.
Increased levels of XIAP are related with expanded tumor cell survival because of diminished apoptosis [31].

\section{Role of Adiponectin in Cancer}

Adiponectin is created exclusively by fat tissue, is copiously present in the plasma, and is conversely identified with the level of adiposity [32]. It implies its fixation in the serum is diminished in weight. A low serum level of adiponectin is related with an expanded danger of different sorts of malignancies [33], for example gastric [34], breast [35-37] , prostate [38, 39], endometrial cancer [40-42], renal cell carcinoma [43], and leukemia [44, 45], and additionally colorectal tumor it indicates cancer patient have smaller adiponectin level [46]. It actuates AMP-activated protein kinase (AMPK), fortifies unsaturated fat oxidation, enhances insulin affectability and glucose digestion [47], goes about as a direct endogenous inhibitor of inflammation and angiogenesis, and diminishes tumor intrusiveness [48-50].

Role of Leptin in Cancer Through Angiogenesis: Biological mechanism for synthesis of new growing blood vessels from preexisting ones is known as Angiogenesis. various type of pathological and physiological conditions most commonly healings of wound, development of tumor, menstrual cycles, cardiovascular diseases, glands of placenta and mammary growth during pregnancy, retinopathies, and atherosclerosis are the important role of angiogenesis [51]. Tumor tissues required oxygen and nutrients for rapidly growing, so in order to supply nutrient angiogenesis (major factor of caner spread) is stimulated. So, the outburst of tumor cells reflect the expression of angiogenic factors [52]. Leptin become the cause of over expression of vascular endothelial growth factor (VEGF) that ultimately promote the growth of mammary atumor [53]. Leptin act as angiogenesis inducer that lead to formation of 3D capillary like tubes, vascular endothelial growth factor (VEGF) also lead this. VEGF165 is supported by leptin considered as a major proangiogenic factor just like endothelial growth factor [54]. The appearance of the VEGF family in tumor cells and nearby stroma is depend upon growth factors like cytokines, once VEGF family appear it involved in neovascularization [55]. Neovascularization (tumor angiogenesis) consist of 4 steps. First, the tissue of basement membrane is damaged, that leads to current devastation and hypoxia. Second, endothelial cells migrate that are activated by angiogenic factors (VEGF).

Third is proliferation and stabilization of endothelial cells. Fourth, angiogenic process is continuously regulated by angiogenesis regulating factors [52]. Tumor cells produce VEGF and secreted it in extracellular space that produce new blood vessels upon which tumor cells depends for feeding and growing. Tumor cells upon confrontation endothelial cells, bind to specific receptor on membrane of end othelial cell. Upon binding of VEGF to its respective receptor it activates co-stimulatory proteins that are responsible for transmitting signal in nucleus ultimately synthesized product by modifying genes, those products required for new endothelial 
cell growth [56]. Meanwhile, leptin induced angiogenesis indirectly by selection of matrix metalloproteinase 2 (MMP 2) [57] metalloproteinases (MMPs) produced by VEGF induced activation of endothelial cells. The MMPs cleave the extracellular matrix that ample the gap between cells and is composed of polysaccharides and protein. This matrix allows the passage of endothelial cells as well as uncontrolled division and migration into surrounding cells. These large number of endothelial cells of organized in the form of hollow tubes that under the effect of adhesion factor like integrin $\alpha$ or $\beta$ evolve gradually into a mature network of blood vessels [56]. The existence of isoform (short and long) receptors of the leptin hormone appear on the surface of endometrial cancer cells can ultimately increase the growth of endometrial cancer and it proliferate through JAK/STAT and AKT mechanism in a matrigel invasion assay [58]. The mechanism through which leptin promote angiogenesis in pathological and physiological conditions as demonstrated in figure [59]. Angiogenesis causes these cancers through VEGF pathway activated by leptin [52] (Figure 2).

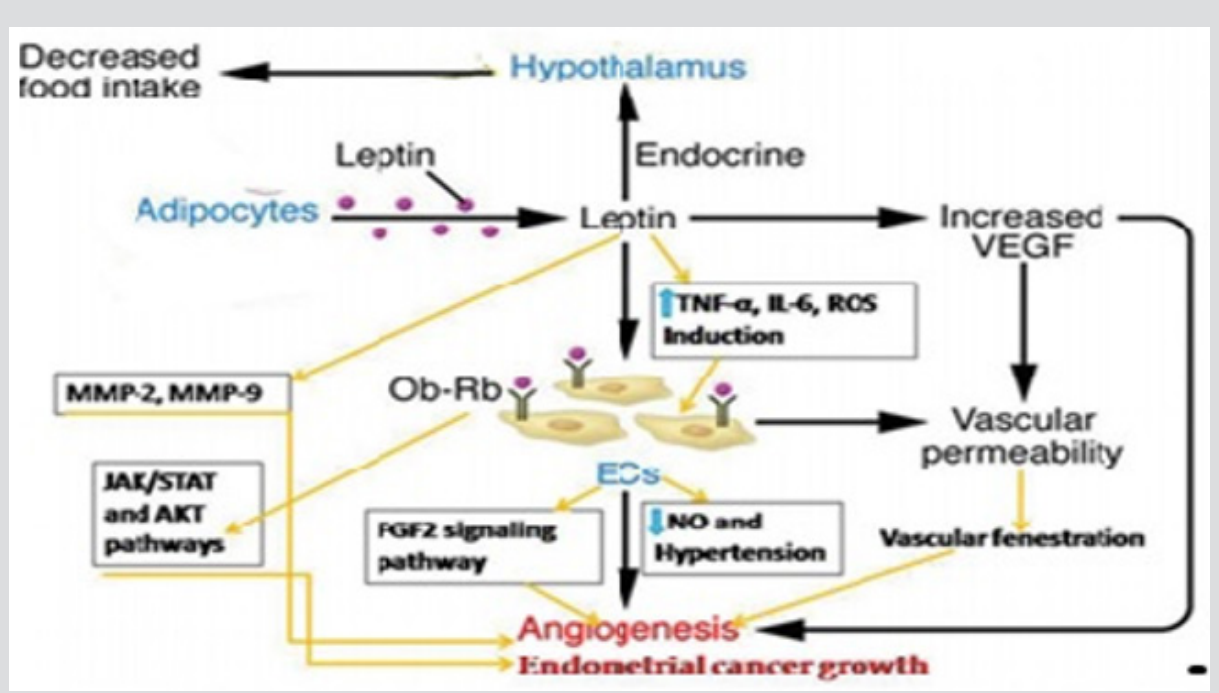

Figure 2: Leptin secreted by adipocytes increase VEGF, that cause vascular permeability that lead to angiogenesis through vascular fenestration, leptin binds to it receptor and increase that again increase cytokines that lead to angiogenesis.

Role of Leptin in Breast Cancer: The danger of the breast cancer in women increase in postmenopausal and decrease in premenopausal which is associated with the body mass index (BMI, weight/height2)[60].The percentage and amount of adipose tissue is reflected by the circulating level of leptin hormone, with a correlation coefficient around 0.8 between serum leptin and various measurement of the body fats. Its level decreases in decreasing adipose tissues and the level of physical activity is inversely to the circulating level of leptin during the weight loss [61]. The levels of leptin are related to nutritional status and delivers information's about the size of energy stores to brain [62]. Adipokines (leptin, adiponectin, and hepatocyte growth factor [HGF]) interact with pre-neoplastic or cancerous breast epithelium in case of obesity and breast cancer with circulate in plasma. Endocrine, paracrine and autocrine mediated relationship caused by leptin and cellular microenvironment which support the growth of tumor via leptin and estrogen receptor activation. Figure 3 A paracrine relationship exists between nearby tumor cells and HGF-synthesizing adipocytes to stimulate the growth. Adiponectin has direct inhibitory effect on growth of tumor cells and leptin secreted from the surroundings of breast cells block and inhibits inflammatory cytokines (tumor necrosis factor $\alpha$ and interleukin-1 $\beta$ [TNF- $\alpha$ and IL-1 $\beta]$ ) which produces macrophages. HGF, hepatocyte growth factor; TNF- $\alpha$, tumor necrosis factor- $\alpha$; IL-1 $\beta$, interleukin-1 $\beta$; Ma, macrophage [63-65].

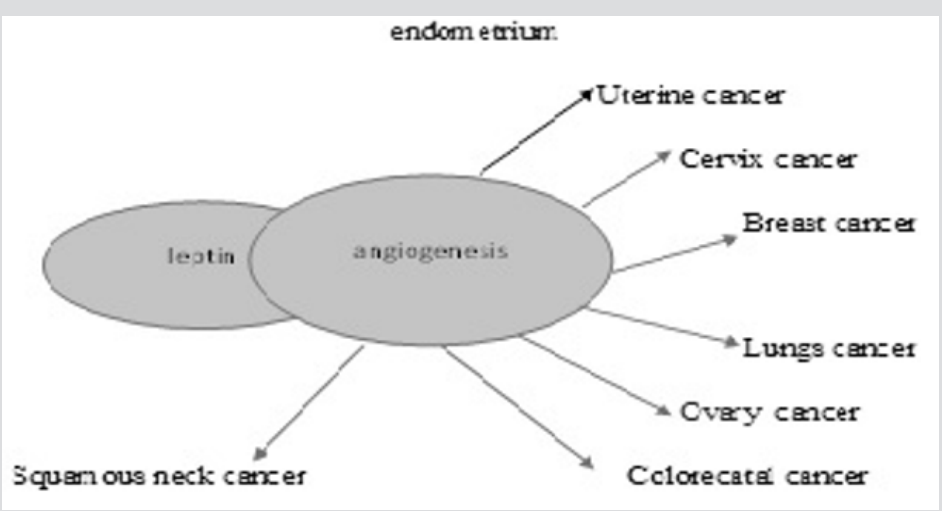

Figure 3: Involvement of leptin in different cancers through angiogenesis process. 
Role of Leptin in Colon Cancer: The elevated level of serum leptin, adipocytes -derives hormone and insulin in obesity cause colorectal cancer $[2,60]$. Its receptors are present in human colon cell lines, polp and adjacent mucosa. It causes the proliferation, invasiveness and increased serum leptin of colonic cells. Leptin also initiates the angiogenesis which cases proliferation, tumor growth and metaastasis. It is a link between colon cancer risk and obesity and also cause tumor genesis in colon cancer [66,67]. Western- style diet leads to increase adiposity and changes in the microbiota to adapt to the increased energy supply. Adipokines such as leptin and adiponectin could allow to establishment of tumor microenvironment Figure 4. In obese subject, hyperlipidemia and insulin resistance lead to low-grade systemic inflammation, which promotes proliferation of tumor cells and angiogenesis and reduced apoptosis process. These mechanisms are likely to vary among subject and little is known about their interaction [68].

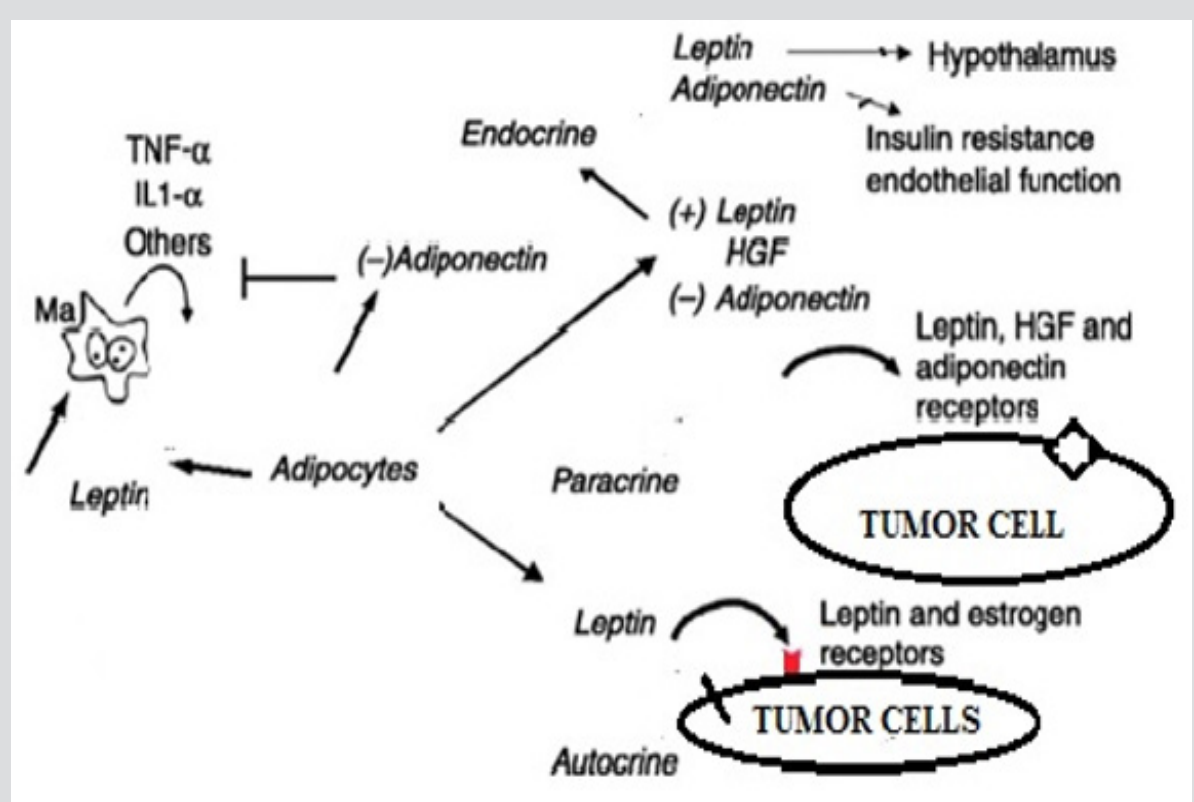

Figure 4: leptin is secreted by adipokines which involve in tumor growth in breast epithelium, which have relation endocrine and autocrine via between leptin and estrogen.

Role of Leptin in Thyroid Cancer: Thyroid malignancy is the most well-known endocrine tumor. Expanded articulation of leptin and its receptor in papillary thyroid tumor has been demonstrated. This hormone presumably through its receptor and enactment of the PI3K/AKT pathway assumes a vital part in papillary thyroid tumor pathogenesis [69]. It additionally appears that the oncogenic impacts of leptin on papillary thyroid carcinoma cells are identified with the invigorating cell multiplication and inhibit apoptosis [70]. Pathway has been illustrated in figure 5 [31].

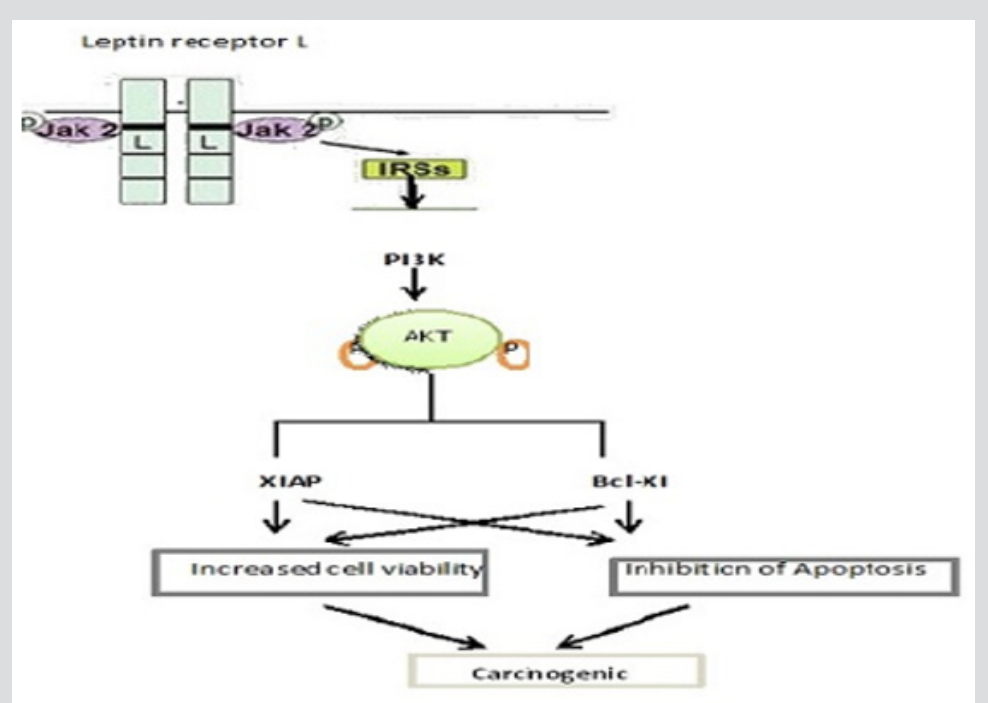

Figure 5: Leptin/Ob-Rb restricting outcomes in insulin receptor substrate (IRS) phosphorylation, which thusly activates PI3K/ AKT pathway through the relationship of IRS with the administrative subunit p85 of AKT. Actuated AKT thusly phosphorylates XIAP (an individual from antiapoptotic proteins) hence inhibiting its degradation, which prompts diminished caspase-3 action and diminished apoptosis. 
Role of Leptin In Pancreatic Cancer: Pancreatic cancer (PC) is the fourth major case of cancer death in Western countries [71] Among $80 \%$ of all pancreatic cancer, the most important malignancy is pancreatic adenocarcinoma [71,72]. The several bioactive adipokines recognize active endocrine organs by adiopose tissue which carryout many pathological and physiological processes like insulin resistance and sensitivity, appetite, immunity, hematopoiesis and angiogenesis. Leptin and adiponectin are two important adipokines $[73,74]$. The insulin resistance relates with low level of leptin whereas insulin-sensitizing, anti-inflammatory and anti-atherogenic adipokines relates with low level of adiponectin have protective role in malignancies of several types [75]. Leptin promotes vascularization, proliferation, migration and invasion of tumor cells. Obesity promotes pancreatic carcinogenesis and increase leptin concentration [76]. Obesity also changes other adipokines and growth factor, fatty infiltration of pancreas, high leptin level in pancreatic tissues, 2-folds higher serum leptin concentration and noticeable increase in number of pancreatic tumors (Figure 5). Serum leptin is more sensitive marker for intra-abdominal or visceral adiposity which relates with body mass index [77].

Leptin and Natural Killer: Innate and adaptive immunity both are regulated by leptin. It increases Th17 proliferation, cytokine generation and granulocyte chemotaxis Figure 6. Higher level of leptin restrain separation of $\mathrm{CD} 4+\mathrm{T}$ cell into administrative $\mathrm{T}$ cell and NK cell show weakened cytotoxicity under similar condition [79]. Reduced production of it decreased lymphocyte proliferation, decreased macrophage phagocytic activity (defective immune response) $[80,81]$.

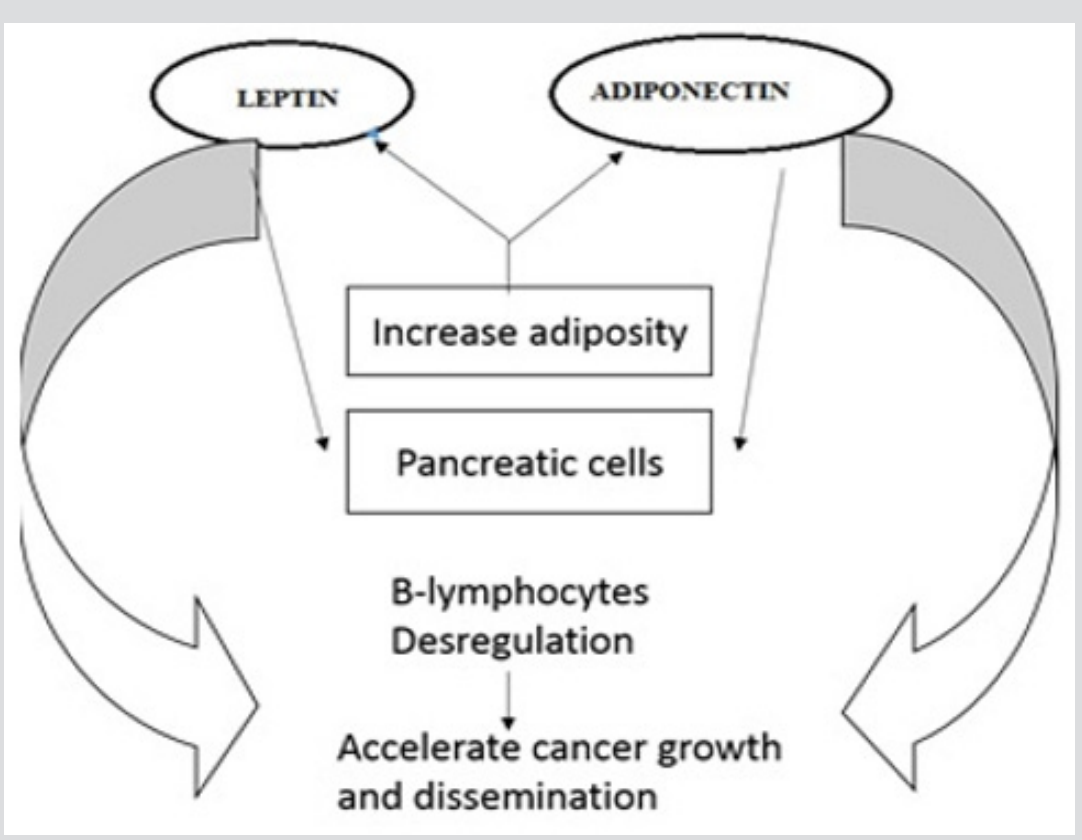

Figure 6: Increase level of leptin and decrease level of adiponectin in pancreatic cancer cause B-lymphocyte dysregulation and accelerate cancer.

Leptin Regulates Apoptosis Through Natural Killer Cell:

Typical level of leptin upgrades release of perforin, granzyme B, Fas ligand [Fas-L], interferon gamma andtumor-necrosis-factor-related apoptosis-inducing ligand [TRAIL] (effectors required in cytotoxic action) from NK. These expand activity of NK to slaughter cytotoxic cell. However, long time and higher level of leptin increases the level of TRAIL and IFN- $\gamma$, above the normal, and reduced the level of all other effectors. The expanded articulation of TRAIL and IFN- $\gamma$ upgrades the cytotoxic action against typical cells and decreases the cytotoxic action against target cell [79]. NK cells show decreased surface TRAIL, a marker of degranulation, a cytolysis ligand, and CD107 and NK action [82]. An expanded articulation of perforin, TRAIL and IFN- $\gamma$ express on NK cell, on administration of leptin to NK cell that enhance cytotoxic activity [82-84].
Diminished IFN- $\gamma$ generation and cytotoxity against tumor cell occur on incubation of NK with leptin for longer time and higher concentration for example incubation in $10 \mathrm{ng} / \mathrm{ml}$ for $3-4$ day or $100 \mathrm{ng} / \mathrm{ml}$ for 1-2 day [83-85] It means typical level of leptin is needed for NK effector system, with brief increment in leptin NK activity increase, but long term administration suppress NK activity [79]. The cells that are resistant against TRAIL and Fas-L require other mechanism for their lysis i-e using receptor of NK cell such as NKp30, NKp46 and NKG2D. These receptors are regulated by leptin. Blocking of these receptors decreases the cytotoxic activity [84]. In cancer patient NK cell lose their ability to kill cancer cell. To overcome this problem or for killing the cancer cell, there is a need to activate the NK and its function. Level of leptin increased during cancer. Leptin can be used to regulate the NK activity as shown in Table 1. 
Table 1: Regulation of natural killer cells through leptin, Normal leptin level regulates natural killer cells' activity that inovolved in treatment of cancer naturally. However, by increasing leptin level, NK cells hyper-regulate and through different mechanism became toxic to normal cells instead of cancerous cells.

\begin{tabular}{|c|c|c|c|c|}
\hline Leptin Level & $\begin{array}{l}\text { Secretions of } \\
\text { Natural Killer }\end{array}$ & Regulation of Effectors by Leptin & $\begin{array}{c}\text { Mechanism Through Which NK Involve in } \\
\text { Cancer Therapy }\end{array}$ & References \\
\hline \multirow{3}{*}{ Normal level } & Granzyme & $\begin{array}{c}\text { Administration of leptin to NK cell } \\
\text { increases expression of perforin } \\
\text { and granzyme and its cytotoxic } \\
\text { action. }\end{array}$ & $\begin{array}{l}\text { Granule exocytosis pathway: } \\
\text { When NK cell interacts with cancer cell, cytotoxic } \\
\text { granules (perforin and granzyme) release from } \\
\text { NK cell. Perforin interacts with cell membrane } \\
\text { and forms a pore on the surface of target cell for } \\
\text { the entry of granzyme. This granzyme activates } \\
\text { apoptosis of cancer cell. }\end{array}$ & \multirow{3}{*}[82-84,86]{} \\
\hline & TRAIL & $\begin{array}{l}\text { Administration of leptin to NK } \\
\text { cell increases expression of FAS-L, } \\
\text { TRAIL and its cytotoxic action }\end{array}$ & $\begin{array}{l}\text { Death receptor pathway: } \\
\text { Receptor of FAS and TRAIL (tumor-necrosis-factor- } \\
\text { related apoptosis-inducing ligand) is present on } \\
\text { cancer cell it binds with ligand of FAS and TRAIL } \\
\text { (present on the surface of NK cell). On interaction } \\
\text { it forms a complex to activate NK cell and to release } \\
\text { signal that mediate apoptosis of cancer cell. }\end{array}$ & \\
\hline & $\mathrm{IFN} \gamma$ & $\begin{array}{l}\text { Administration of leptin to NK cell } \\
\text { increases production of IL- } 2 \text { and IL- } \\
15 \text { that enhance release of IFN } \gamma\end{array}$ & $\begin{array}{l}\text { IFN } \gamma \text { activates T-cell and mediates apoptosis } \\
\text { through Jak and STAT signaling. }\end{array}$ & \\
\hline $\begin{array}{l}\text { High level of leptin for } \\
\text { long time }\end{array}$ & & $\begin{array}{l}\text { Administration of leptin to NK cell } \\
\text { increases production of TRAIL and } \\
\text { IFN } \gamma \text { above the normal level }\end{array}$ & $\begin{array}{l}\text { High level of TRAIL and IFN } \gamma \text { shows toxic effect } \\
\text { against normal cell instead of cancer cell. }\end{array}$ & [79] \\
\hline $\begin{array}{l}\text { High or low level of } \\
\text { leptin for short or long } \\
\text { time respectively }\end{array}$ & & $\begin{array}{l}\text { Incubation of NK in leptin } 100 \mathrm{ng} / \\
\text { ml for } 1-2 \text { day or } 10 \mathrm{ng} / \mathrm{ml} \text { for } 3-4 \\
\text { day. }\end{array}$ & $\begin{array}{c}\text { Diminished IFN }-\gamma \text { generation and cytotoxity against } \\
\text { tumor cell. }\end{array}$ & [83-85] \\
\hline
\end{tabular}

\section{Leptin Manipulation to Treat Cancer}

A number of methods have been devised to bring leptin levels down, which might be helpful for cancer patients who have elevated levels of leptin [87]. An interesting way to interfere leptin signaling is to increase adiponectin, another adipocytokine which is negatively related to obesity. Adiponectin has effective insulin-sensitization, anti-inflammatory and atherogenic. Adiponectin levels are low in obesity and diseases associated with it. Previous researches have clearly shown the relevance of adiponectin with treatments, which forms a basis to use adiponectin to suppress the cancerous effects of leptin. An efficient strategy to increase adiponectin is the use of Thiozolidinediones (TZDs). TZDs are known to enhance adiponectin which inhibits the growth and invasion of cell which is induced by leptin elevated levels $[33,88]$. Metformin is a biologically active compound which inhibits the growth of cell by inducing AMPK signaling [89]. Benzyl isothiocayanite is also involved in inhibition of leptin signalling and its consequences on cell growth.

Benzyl isothiocyanate inhibits oncogenic actions of leptin in human breast cancer cells by suppressing activation of signal transducer and activator of transcription 3 [90]. Exercise and weight loose is also associated with elevated levels of adiponectin which is helpful in reducing cancer risk [91]. Effects of energy restriction and wheel running on mammary carcinogenesis and host systemic factors in a rat model [92]. In short, there are many ways to enhance adiponectin which effectively inhibit leptin. In metastasis there is over production of leptin and leptin receptors, high circulating levels of leptin are lowered down by addition of soluble leptin receptors. Leptin signaling pathways can be inhibited by using antagonists for leptin receptors. Another effective way is to develop nanobodies that specifically target the leptin receptor $[87,93]$. Some leptin antagonists are the peptides having similar sequences to leptin i-e LPA-2 and LP-1, they show leptin inhibiting activities [94,95].

\section{Conclusion}

There is a consistent confirmation that leptin is related with immunity, cause cancer and other autoimmune diseases. High level of leptin expands articulation of anti-apoptotic proteins, TNF- $\alpha$ and angiogenic factor which promotes cancer cell survival and proliferation. Tumor cells produce the hormone i.e. leptin, this can turn into an objective for medication that reduced leptin level might be prove beneficial in the treatment of cancer. To beat expanding challenges there is a need to determine appropriate and inexpensive method for the treatment of cancer. Development of plenty of agent is important to modulate leptin signaling so it can be used in cancer therapy. Future research ought to concentrate on the strategies of identifying best neutraceutical that can bring the level of leptin at normal. More noteworthy comprehension of the connection between leptin and NK could enhance clinical administration and therapeutic options for patients that are suffering from cancer. 


\section{References}

1. F Lago, C Dieguez, J Gómez-Reino, O Gualillo (2007) The emerging role of adipokines as mediators of inflammation and immune responses Cytokine \& growth factor reviews 18(3-4): 313-325.

2. E E Calle, C Rodriguez, K Walker-Thurmond, MJ Thun (2003) Overweight, obesity, and mortality from cancer in a prospectively studied cohort of US adults, New England Journal of Medicine, 348: 1625-1638.

3. Q Zheng, SM Dunlap, J Zhu, E Downs-Kelly, J Rich, et al. (2011) Leptin deficiency suppresses MMTV-Wnt-1 mammary tumor growth in obese mice and abrogates tumor initiating cell survival, Endocrine-related cancer 18(4): 491-503.

4. L Hardie, N Guilhot, P Trayhurn (1996) Regulation of leptin production in cultured mature white adipocytes, Hormone and Metabolic Research 28(12): 685-689.

5. C Garofalo, E Surmacz (2006) Leptin and cancer, Journal of cellular physiology 207(1): 12-22.

6. S Miyazawa-Hoshimoto, K Takahashi, H Bujo, N Hashimoto, K Yagui, et al. (2005) Roles of degree of fat deposition and its localization on VEGF expression in adipocytes, American Journal of Physiology-Endocrinology and Metabolism 288(6): E1128-E1136.

7. H K Park, RS Ahima (2014) Leptin signaling, F1000Prime Rep 6: 6-73.

8. A Oswal, G Yeo (2010) Leptin and the control of body weight: a review of its diverse central targets, signaling mechanisms, and role in the pathogenesis of obesity. Obesity 18(2): 221-229.

9. J R Revollo, A A Grimm, S I Imai (2007) The regulation of nicotinamide adenine dinucleotide biosynthesis by Nampt/PBEF/visfatin in mammals. Current opinion in gastroenterology 23(2): 164-170.

10. S E Choi, T Fu, S Seok, DH Kim, E Yu, et al. (2013) Elevated microRNA-34a in obesity reduces NAD+ levels and SIRT1 activity by directly targeting NAMPT Aging cell. 12(6): 1062-1072.

11. RS Ahima, D Prabakaran, C Mantzoros, D Qu (1996) Role of leptin in the neuroendocrine response to fasting. Nature 382(6588): 250-252.

12. E Surmacz (2007) Obesity hormone leptin: a new target in breast cancer? Breast Cancer Research 9(1): 301.

13. C Garofalo, M Koda, S Cascio, M Sulkowska, L Kanczuga-Koda, et al. (2006) Increased expression of leptin and the leptin receptor as a marker of breast cancer progression: possible role of obesity-related stimuli. Clinical Cancer Research 12(5): 1447-1453.

14. M Ishikawa, J Kitayama, H Nagawa (2004) Enhanced expression of leptin and leptin receptor (OB-R) in human breast cancer. Clinical Cancer Research 10(13): 4325-4331.

15. Y Miyoshi, T Funahashi, S Tanaka, T Taguchi, Y Tamaki, et al. (2006) High expression of leptin receptor mRNA in breast cancer tissue predicts poor prognosis for patients with high, but not low, serum leptin levels. International journal of cancer 118(6): 1414-1419.

16. D Magoffin, S Weitsman, S Aagarwal, A Jakimiuk(1999) Leptin regulation of aromatase activity in adipose stromal cells from regularly cycling women Ginekologia polska 70(1): 1-7.

17. E Fiorio, A Mercanti, M Terrasi, R Micciolo, A Remo, et al. (2008) Leptin/ HER2 crosstalk in breast cancer: in vitro study and preliminary in vivo analysis. BMC cancer 8: 305.

18. R Firestein, G Blander, S Michan, P Oberdoerffer, S Ogino, J Campbell, et al. (2008) The SIRT1 deacetylase suppresses intestinal tumorigenesis and colon cancer growth. PloS one 3(4): e2020.

19. J R Knight, J Milner (2012) SIRT metabolism and cancer Current opinion in oncology $24: 68-75$.

20. A Noguchi, K Kikuchi, H Zheng, H Takahashi, Y Miyagi, et al. (2014) SIRT1 expression is associated with a poor prognosis, whereas DBC1 is associated with favorable outcomes in gastric cancer. Cancer medicine 3(6): 1553-1561
21. Y W Cao, W Q Li, G X Wan, Y X Li, X M Du, et al. (2014) Correlation and prognostic value of SIRT1 and Notch1 signaling in breast cancer. Journal of Experimental \& Clinical Cancer Research 33: 97.

22. M Nihal, N Ahmad, GS Wood (2014) SIRT1 is upregulated in cutaneous T-cell lymphoma, and its inhibition induces growth arrest and apoptosis. Cell cycle 13(4): 632-640.

23. H Feng, Q Liu, N Zhang, L Zheng, M Sang, et al. (2014) Leptin Promotes Metastasis by Inducing an Epithelial-Mesenchymal Transition in A549 Lung Cancer. Cells Oncology Research Featuring Preclinical and Clinical Cancer Therapeutics 21: 165-171.

24. I Wolf, S Sadetzki, H Kanety, Y Kundel, C Pariente, et al. (2006) Adiponectin, ghrelin, and leptin in cancer cachexia in breast and colon cancer patients. Cancer 106(4): 966-973.

25. T Jardé, F Caldefie-Chézet, N Goncalves-Mendes, F Mishellany, C Buechler, et al. (2009) Involvement of adiponectin and leptin in breast cancer: clinical and in vitro studies, Endocrine-related cancer 16(4): 1197-1210.

26. KJ Nkhata, A Ray, TF Schuster, ME Grossmann, MP Cleary, et al. (2009) Effects of adiponectin and leptin co-treatment on human breast cancer cell growth. Oncology reports 21(6): 1611-1619.

27. A Ray, KJ Nkhata, MP Cleary (2007) Effects of leptin on human breast cancer cell lines in relationship to estrogen receptor and HER2 status. International journal of oncology 30(6): 1499-1510.

28. N K Saxena, PM Vertino, FA Anania, D Sharma (2007) Leptin-induced growth stimulation of breast cancer cells involve recruitment of histone acetyltransferases and mediator complex to CYCLIN D1 promoter via activation of Stat3. Journal of Biological Chemistry 282(18): 1331613325.

29. M Hoda, S Keely, L Bertelsen, W Junger, D Dharmasena, et al. (2007) Leptin acts as a mitogenic and antiapoptotic factor for colonic cancer cells. British Journal of Surgery 94(3): 346-354.

a. OOgunwobi, I L Beales (2007) The anti-apoptotic and growth stimulatory actions of leptin in human colon cancer cells involves activation of JNK mitogen activated protein kinase JAK2 and PI3 kinase/Akt. International journal of colorectal disease 22(4): 401-409.

30. TF Franke, CP Hornik, L Segev, GA Shostak, C Sugimoto, et al. (2003) PI3K/Akt and apoptosis: size matters. Oncogene 22(56): 8983-8998.

31. T Yamauchi, J Kamon, H Waki, Y Terauchi, N Kubota, et al. (2001) The fat-derived hormone adiponectin reverses insulin resistance associated with both lipoatrophy and obesity. Nature medicine 7(8): 941-946.

32. I Kelesidis, T Kelesidis, C Mantzoros (2006) Adiponectin and cancer: a systematic review. British journal of cancer 94(9): 1221-1225.

33. M Ishikawa, J Kitayama, S Kazama, T Hiramatsu, K Hatano, et al. (2005) Plasma adiponectin and gastric cancer. Clinical Cancer Research 11: 466-472.

34. C Mantzoros, E Petridou, N Dessypris, C Chavelas, M Dalamaga, et al. (2004) Adiponectin and breast cancer risk. The Journal of Clinical Endocrinology \& Metabolism 89(3): 1102-1107.

35. DC Chen, YF Chung, YT Yeh, HC Chaung, F C Kuo, et al. (2006) Serum adiponectin and leptin levels in Taiwanese breast cancer patients. Cancer letters 237(1): 109-114

36. Y Miyoshi, T Funahashi, S Kihara, T Taguchi, Y Tamaki, et al. (2003) Association of serum adiponectin levels with breast cancer risk. Clinical Cancer Research 9(15): 5699-5704

37. S Goktas, MI Yilmaz, K Caglar, A Sonmez, S Kilic, et al. (2005) Prostate cancer and adiponectin. Urology 65(6): 1168-1172.

38. K Michalakis, CJ Williams, N Mitsiades, J Blakeman, S Balafouta-Tselenis, et al. (2007) Serum adiponectin concentrations and tissue expression of adiponectin receptors are reduced in patients with prostate cancer: a case control study. Cancer Epidemiology and Prevention Biomarkers 16(2): 308-313. 
39. L Dal Maso, LS Augustin, A Karalis, R Talamini, S Franceschi, et al. (2004) Circulating adiponectin and endometrial cancer risk. The Journal of Clinical Endocrinology \& Metabolism 89(3): 1160-1163.

40. PT Soliman, D Wu, G Tortolero-Luna, KM Schmeler, BM Slomovitz, et al. (2006) Association between adiponectin, insulin resistance, and endometrial cancer. Cancer 106(11): 2376-2381.

41. AE Cust, R Kaaks, C Friedenreich, F Bonnet, M Laville, et al. (2007) Plasma adiponectin levels and endometrial cancer risk in pre-and postmenopausal women. The Journal of Clinical Endocrinology \& Metabolism 92(1): 255-263.

42. TN Spyridopoulos, ET Petridou, A Skalkidou, N Dessypris, GP Chrousos, et al. (2007) Low adiponectin levels are associated with renal cell carcinoma: A case-control study. International journal of cancer 120(7): 1573-1578.

43. F Avcu, A U Ural, MI Yilmaz, N Bingol, O Nevruz, et al. (2006) Association of plasma adiponectin concentrations with chronic lymphocytic leukemia and myeloproliferative diseases. International journal of hematology 83(3): 254-258.

44. E Petridou, C Mantzoros, N Dessypris, S Dikalioti, D Trichopoulos, et al. (2006) Adiponectin in relation to childhood myeloblastic leukaemia. British journal of cancer 94(1): 156-160.

45. K Otani, S Ishihara, H Yamaguchi, K Murono, K Yasuda, et al. (2017) Adiponectin and colorectal cancer. Surgery today 47(2): 151-158.

46. T Yamauchi, J Kamon, Ya Minokoshi, Y Ito, H Waki, et al. (2002) Adiponectin stimulates glucose utilization and fatty-acid oxidation by activating AMP-activated protein kinase. Nature medicine 8(11): 12881295.

47. N Yamaguchi, JGM Argueta, Y Masuhiro, M Kagishita, K Nonaka, et al. (2005) Adiponectin inhibits Toll-like receptor family-induced signaling. FEBS letters 579(30): 6821-6826.

48. T Yokota, K Oritani, I Takahashi, J Ishikawa, A Matsuyama, et al. (2000) a new member of the family of soluble defense collagens, negatively regulates the growth of myelomonocytic progenitors and the functions of macrophages. Blood 96(5): 1723-1732.

49. E Bråkenhielm, N Veitonmäki, R Cao, S Kihara, Y Matsuzawa, et al. (2004) Adiponectin-induced antiangiogenesis and antitumor activity involve caspase-mediated endothelial cell apoptosis. Proceedings of the National Academy of Sciences of the United States of America 101(8): 2476-2481.

50. E Salehi, FS Amjadi, M Khazaei (2011) Angiogenesis in Health and Disease: Role of Vascular Endothelial Growth Factor (VEGF). Journal of Isfahan Medical School 29(132)

51. N Nishida, H Yano, T Nishida, T Kamura, M Kojiro, et al. (2006) Angiogenesis in cancer. Vascular health and risk management 2(3): 213219.

52. RR Gonzalez, S Cherfils, M Escobar, JH Yoo, C Carino, et al. (2006) Leptin signaling promotes the growth of mammary tumors and increases the expression of vascular endothelial growth factor (VEGF) and its receptor type two (VEGF-R2). Journal of Biological Chemistry 281(36): 2632026328.

53. MRo Sierra-Honigmann, AK Nath, C Murakami, G García-Cardeña, A Papapetropoulos, et al. (1998) Biological action of leptin as an angiogenic factor. Science 281(5383): 1683-1686.

54. J Folkman (1995) Angiogenesis in cancer, vascular, rheumatoid and other disease. Nature medicine 1(1): 27-30.

55. AR Nelson, B Fingleton, ML Rothenberg, LM.Matrisian (2000) Matrix metalloproteinases: biologic activity and clinical implications. Journal of Clinical Oncology 18(5): 1135-1135.

56. H Y Park, HM Kwon, HJ Lim, BK Hong, JY Lee, et al. (2001) Potential role of leptin in angiogenesis: leptin induces endothelial cell proliferation and expression of matrix metalloproteinases in vivo and in vitro. Experimental \& molecular medicine 33(2): 95-102.
57. D Sharma, N Saxena, P Vertino, F Anania (2006) Leptin promotes the proliferative response and invasiveness in human endometrial cancer cells by activating multiple signal-transduction pathways. Endocrinerelated cancer 13(2): 629-640.

58. Y Cao (2007) Angiogenesis modulates adipogenesis and obesity. The Journal of clinical investigation 117(9): 2362-2368.

59. F Bianchini, R Kaaks, H Vainio (2002) Overweight, obesity, and cancer risk. The lancet oncology 3(9): 565-574.

60. J Kanaley, C Sames, L Swisher, A Swick, L Ploutz-Snyder, et al. (2001) Abdominal fat distribution in pre-and postmenopausal women: the impact of physical activity, age, and menopausal status. Metabolism 50(8): 976-982.

61. P Stattin, S Söderberg, T Olsson, G Hallmans, P Lenner, et al. (2004) Plasma leptin and breast cancer risk: a prospective study in northern Sweden. Breast cancer research and treatment 86(3): 191-196.

62. M Gröschl, R Wagner, HG Dörr, W Blum, W Rascher, et al. (2001) Variability of leptin values measured from different sample matrices. Hormone Research in Paediatrics 54(1): 26-31.

63. NF Chu, D Spiegelman, GS Hotamisligil, N Rifai, M Stampfer, et al. (2001) leptin and soluble TNF receptors levels in relation to obesity-related atherogenic and thrombogenic cardiovascular disease risk factors among men. Atherosclerosis 157(2): 495-503.

64. E Petridou, Y Papadiamantis, C Markopoulos, E Spanos, N Dessypris, et al. (2000) Leptin and insulin growth factor I in relation to breast cancer (Greece). Cancer causes \& control 11(5): 383-388.

65. RS Ahima, JS Flier (2000) Adipose tissue as an endocrine organ. Trends in Endocrinology \& Metabolism 11(8): 327-332.

66. L Feng, S Li, Y Li, H Li, L Zhang, et al. (2002) Super-hydrophobic surfaces: from natural to artificial. Advanced materials 14: 1857-1860.

67. I Bähr, V Goritz, H Doberstein, GGR Hiller, P Rosenstock, et al. (2017) Diet-Induced Obesity Is Associated with an Impaired NK Cell Function and an Increased Colon Cancer Incidence. Journal of Nutrition and Metabolism.

68. S Uddin, P Bavi, AK Siraj, M Ahmed, M Al-Rasheed, et al. (2010) Leptin-R and its association with PI3K/AKT signaling pathway in papillary thyroid carcinoma. Endocrine-related cancer 17(1): 191-202.

69. D Dutta, S Ghosh, K Pandit, P Mukhopadhyay, S Chowdhury, et al. (2012) Leptin and cancer: Pathogenesis and modulation. Indian journal of endocrinology and metabolism 16(3): 596-600.

70. D Ahmedin Jemal, R Siegel, Ward E, Murray T, Xu J, et al. (2007) Cancer statistics 2007. Ca Cancer J Clin 57(1): 43-66.

71. W Schima, A Ba-Ssalamah, C Kölblinger, C Kulinna-Cosentini, A Puespoek, et al. (2007) Pancreatic adenocarcinoma. European radiology 17: 638649 .

72. G Matarese, C Mantzoros, AL Cava (2007) Leptin and adipocytokines: bridging the gap between immunity and atherosclerosis. Current pharmaceutical design 13(36): 3676-3680.

73. E E Kershaw, JS. Flier (2004) Adipose tissue as an endocrine organ. The Journal of Clinical Endocrinology \& Metabolism 89(6): 2548-2556.

74. M Dalamaga, I Migdalis, JL Fargnoli, E Papadavid, E Bloom, et al. (2009) Pancreatic cancer expresses adiponectin receptors and is associated with hypoleptinemia and hyperadiponectinemia: a case-control study. Cancer Causes \& Control 20(5): 625-633.

75. JO Alemán, LH Eusebi, L Ricciardiello, K Patidar, AJ Sanyal, et al (2014) Mechanisms of obesity-induced gastrointestinal neoplasia. Gastroenterology 146(2): 357-373.

76. RZ Stolzenberg-Solomon, CC Newton, DT Silverman, M Pollak, LM Nogueira, et al. (2015) Circulating leptin and risk of pancreatic cancer: a pooled analysis from 3 cohorts. American journal of epidemiology 182(3): 187-197. 
77. L Marroquí, A Gonzalez, P Ñeco, E Caballero-Garrido, E Vieira, et al. (2012) Role of leptin in the pancreatic $\beta$-cell: effects and signaling pathways. Journal of molecular endocrinology 49(1): R9-R17.

78. C Naylor, WA Petri (2016) Leptin regulation of immune responses. Trends in molecular medicine 22(2): 88-98.

79. S Loffreda, S Yang, H Lin, C Karp, M Brengman, et al. (1998) Leptin regulates proinflammatory immune responses. The FASEB Journal 12(1): 57-65.

80. GM Lord, G Matarese, JK Howard, RJ Baker, SR Bloom, et al. (1998) Leptin modulates the T-cell immune response and reverses starvation-induced immunosuppression. Nature 394(6696): 897-901.

81. T Laue, CD Wrann, B Hoffmann-Castendiek, D Pietsch, L Hübner, et al. (2015) Altered NK cell function in obese healthy humans. BMC obesity 2: 1

82. J Jahn, M Spielau, C Brandsch, GI Stangl, KS Delank, et al. (2015) Decreased NK cell functions in obesity can be reactivated by fat mass reduction. Obesity 23(11): 2233-2241.

83. B Lamas, N Goncalves-Mendes, R Nachat-Kappes, A Rossary, F CaldefieChezet, et al. (2013) Leptin modulates dose-dependently the metabolic and cytolytic activities of NK-92 cells. Journal of cellular physiology, 228(6): 1202-1209.

84. CD Wrann, T Laue, L Hübner, S Kuhlmann, R Jacobs, et al. (2012) Short-term and long-term leptin exposure differentially affect human natural killer cell immune functions. American Journal of PhysiologyEndocrinology and Metabolism 302(1): E108-E116.

85. MJ Smyth, Y Hayakawa, K Takeda, H Yagita (2002) New aspects of natural-killer-cell surveillance and therapy of cancer. Nature Reviews Cancer 2(11): 850-861.

86. A Gertler (2006) Development of leptin antagonists and their potential use in experimental biology and medicine. Trends in Endocrinology \& Metabolism 17(9): 372-378.

\section{ISSN: 2574-1241}

DOI: 10.26717/BJSTR.2019.18.003091

Tazeen Rao. Biomed J Sci \& Tech Res

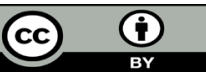

This work is licensed under Creative Commons Attribution 4.0 License

Submission Link: https://biomedres.us/submit-manuscript.php
87. R Govindarajan, L Ratnasinghe, DL Simmons, ER Siegel, MV Midathada, et al. (2007) Thiazolidinediones and the risk of lung, prostate, and colon cancer in patients with diabetes. Journal of Clinical Oncology 25(12): 1476-1481.

88. AM Gonzalez-Angulo, F Meric-Bernstam (2010) Metformin: a therapeutic opportunity in breast cancer. Clinical cancer research 16(6): 1695-1700.

89. S H. Kim, A Nagalingam, NK Saxena, SV Singh, D Sharma, et al. (2011) Benzyl isothiocyanate inhibits oncogenic actions of leptin in human breast cancer cells by suppressing activation of signal transducer and activator of transcription 3. Carcinogenesis 32(3): 359-367.

90. Z Zhu, W Jiang, JH Zacher, ES Neil, JN McGinley, et al. (2012) Effects of energy restriction and wheel running on mammary carcinogenesis and host systemic factors in a rat model. Cancer Prevention Research 5(3): 414-422.

91. J Steiner, J Davis, J McClellan, R Enos, E Murphy, et al. (2013) Effects of voluntary exercise on tumorigenesis in the C3 (1)/SV40Tag transgenic mouse model of breast cancer. International journal of oncology 42(4): 1466-1472.

92. G Solomon, L NIV-SPECTOR, D GONEN-BERGER, I Callebaut, J Djiane, et al. (2006) Preparation of Leptin Antagonists by Site-Directed Mutagenesis of Human, Ovine, Rat, and Mouse Leptin's Site III. Annals of the New York Academy of Sciences 1091: 531-539.

93. RR Gonzalez, PC Leavis (2003) A peptide derived from the human leptin molecule is a potent inhibitor of the leptin receptor function in rabbit endometrial cells. Endocrine 21(2): 185-195.

94. A Gertler, G Solomon (2013) Leptin-activity blockers: development and potential use in experimental biology and medicine 1. Canadian journal of physiology and pharmacology 91(11): 873-882.

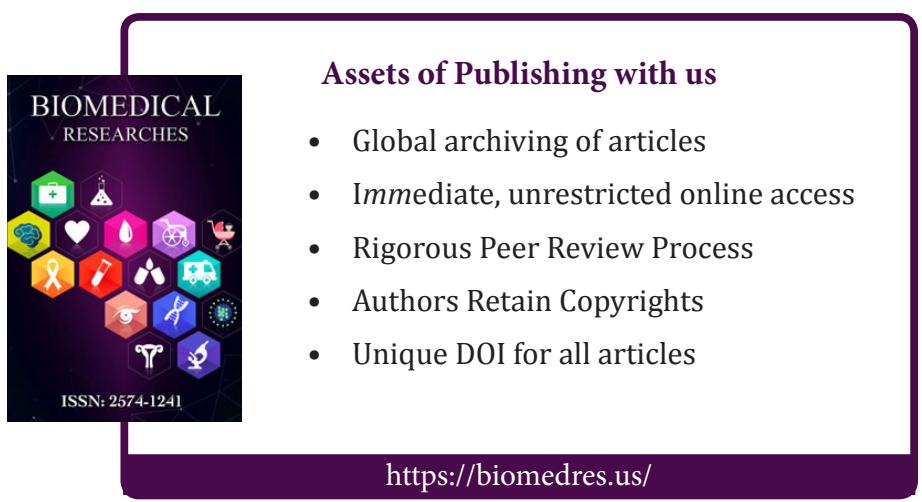

